\title{
WHEN SANTIAGO DE COMPOSTELA AND MONDOÑEDO WERE BUILT IN WOOD: HALF TIMBER WITH EARTH CONSTRUCTIONS IN THE CITIES OF GALICIA.
}

\author{
A. Fernández Palicio ${ }^{1, *}$ \\ ${ }^{1}$ SeteOitavas Sociedade Cooperativa Galega. Vigo, Galicia 36202 - alejandro@ seteoitavas.com \\ Laboratorio de Tecnoloxías Apropiadas Vigo, Galicia 36202 - tecnoloxiasapropiadas@ gmail.com
}

\author{
Commission II - WG II/8
}

KEY WORDS: Half-timber with earth, Galicia, earth construction, Middle Age, urban architecture

\begin{abstract}
:
Nowadays, more common traditional constructions in Galician historical cities are houses with stone walls and wood slabs. However, Galician medieval cities were built with half timbers with earth and bricks used as structural closures and recovered interiorly with mud and lime mortars. At that time, Santiago de Compostela and Mondoñedo were two cities built in wood, not in stone and these half timbers were the most widespread technique in these cities until the XVIII and XIX. Only a few examples can be seen at present. These constructions are on the brink of disappearance due to three main factors: the lack of general public knowledge, the lack of Government protection and, finally, the lack of building professional training in the aforementioned techniques.
\end{abstract}

\section{INTRODUCTION}

\subsection{About this research}

This research aims to provide an overview of the first urban housing types in several Galician cities since its foundation until its transformation during the eighteenth and nineteenth century. These dwellings have a timber frame structure filled with earth and brick coated with lime and clay over a stone-built lower storey and a gabble roof.

\subsubsection{Resources used}

The main sources of information were texts by urban historians as far as documentary framework is concerned. Interviews with civil servants from City Council Rehabilitation Offices and technical experts who managed timber frame constructions renovation works were fundamental to achieving this objective. At the same time, the research was completed with an important field work in several historical centres with field visits to private properties when we have the approval of their owners.

\subsubsection{Difficulties}

The difficulties encountered have been many. On the one hand, the scarcity of well-preserved half-timbered houses has required a careful search in historic urban settings in order to find examples of distinct typological elements. On the other hand, there are few studies of medieval urban architecture in the Iberian Peninsula. Investigations about medieval urban Galician architecture have hardly begun which have required obtaining references from elsewhere in the north of the Peninsula. Galician vernacular architecture monographs contained, by and large, rural buildings researchs, but urban settings have not received the same attention having very little historical studies about vernacular urban housing.
Finally, we have verified that a large part of the already scarce heritage that was left standing was destroyed in the last two decades without being documented by technical services that carried out the works, which makes it more necessary an urgent this research.

\subsection{On the perception of traditional construction in Galicia}

Main Galician vernacular architecture monographs during the past 40 years (De Llano, 1996; Bas, 2002; Caamaño, 2006), which have defined the existing collective imaginary on the evolution of the constructive material culture in Galicia, focused their attention on the constructions of vernacular architecture that were gradually consolidating during the XVIII and XIX centuries and that had stone as their main material element, hardly showing examples of constructions not erected with stone or without consider the evolution of their own constructive processes; regardless of the paths tested by the pioneers of material culture (Lorenzo Fernández, 1962; Otero Pedrayo, 1927; López Cuevillas, 1973) in terms of attention to the study of urban constructions or the use of half timbers (Figure 1).
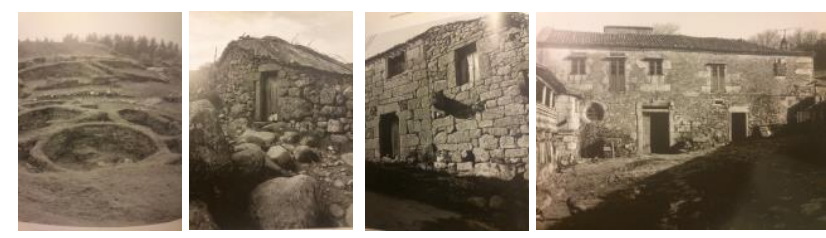

Figure 1. Evolutionary sequence of Galician vernacular architecture between the Neolithic and the XIX century. Source: (De Llano, 1983).

This smaller attention to the evolution and adaptation of vernacular architecture has favoured a perception of linearity and continuity between the Neolithic stone housing and the modern age stone dwelling, which has partially distorted the enormous wealth of the adaptive process over the centuries, diminishing the field of vision of the subject area. This research aims to expand this field.

\footnotetext{
* Corresponding author
} 


\section{MEDIEVAL URBAN HOUSING IN GALICIA}

\subsection{Urban spatial planning}

Urban life begins to slowly reappear in Galicia during the IX and $\mathrm{X}$ century in a context in which Europe experiences a revival of their cities. There is a need in an unstable Galicia to reorganise its empty territory in order to repopulate it, leaning on the urban settlements that had kept the inherited road network active. Thus, the origins of the Galician cities date back to the XI century and the first half of the XII century when the new boroughs of the main cities of the Roman, Suevian and Visigoth periods were consolidating, (Lugo, Ourense and Tuy), with the addition of the episcopal cities of Compostela and Mondoñedo (López Alsina, 1976) and the new foundations of Allariz and Ferrol (Solano FernándezSordo, 2010).

The period of security and commercial expansion between the north of the peninsula and Europe that lasted until the first third of the XIII century will promote the foundation of a series of villas on small port establishments (Ribadeo, Viveiro, Ortigueira, Betanzos, A Coruña, Noia, Padrón, Pontevedra, Baiona, A Guarda and Salvaterra). In addition, they have founded the cities of Ribadavia and Verín in inland áreas; and Melide, Sarria and Triacastela along the Way to Santiago. In the final two thirds of the XIIIth century, the cities of Cedeira, Neda, Pontedeume, Muros, Caldas de Reis, Redondela and Monterrei will be founded.

In this way, in just two centuries the Galician territory will create a series of nodes to control the territory to which we must add the small enclaves linked to pilgrimages (Palas de Rey, Portomarín, Leboreiro, Arzúa and Fonsagrada) and seaports (Portonovo, Rianxo, Cambados, Vigo, Cangas de Morrazo, Muxía, Laxe and Foz) (Figure 2).

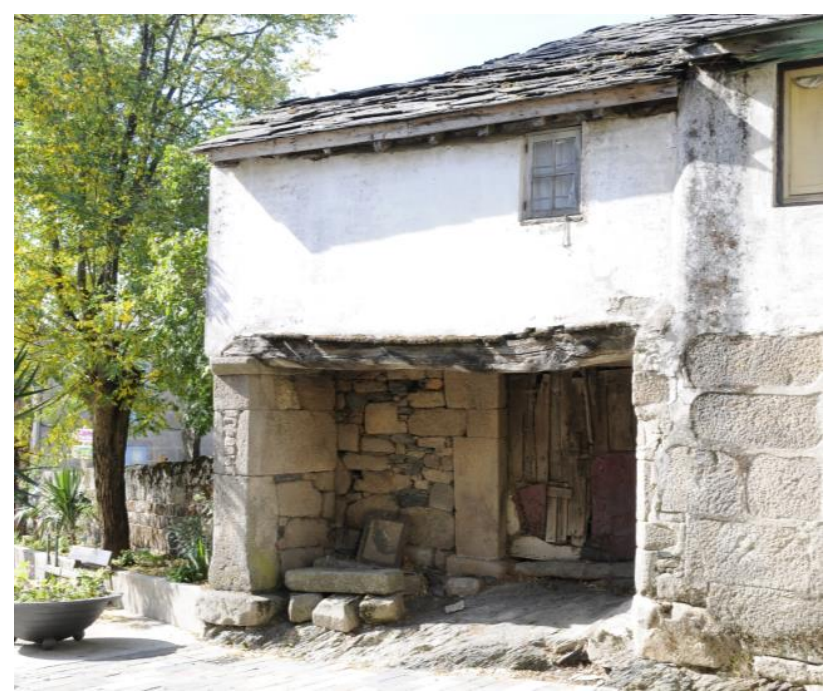

Figure 2. Medieval typology house with stone ground floor and half-timbered floor in A Gudiña settlement located on the Santiago route from the south. Source: A.F.P.

\subsection{Foundational characteristics of cities}

The rise of the urbanization process between the XIth and XIVth centuries will create across Europe a significant network of concentrated urban habitats in a process unparalleled with another similar historical moment (Arízaga Bolomburu, 1993).
The new cities will have, throughout the West, homogeneous elements despite chronological and foundational differences or other particularities. They were built according to a plan prefixed by the colonizers where the distribution, length and width of their streets as well as their public space were indicated. It was a regular design although adapted to the conditions of the place, with parallel streets cut by other smaller ones at right angles, which defined blocks that would be divided into parcels of houses, generally homogeneous. As the development of the cities advances, the street will become a showcase of wealth, with the consequent care of facades and paving; and with the growing concern for hygiene, safety and the control of urban irregularities, circumstances that will become stronger as the decades go by. (Ladero Quesada, 1998).

\subsection{The appearance of half-timbered houses.}

Once the huts (buildings excavated in the ground with posts driven into the ground and walls of branches interwoven with mud and straw) were widely disappeared in Atlantic Europe around the year 1000, the elemental house, made up of unworked stone or earth walls and branch roofing, will dominate the landscape in rural areas (García Camino, 1998).

The new city foundations will implement a housing typology that can be found, with various variations, throughout the north of the Iberian Peninsula (Flores López, 1973) as well as in western Europe (López Carreira, 1999). They were halftimbered houses, with stone foundations, a ground floor of stone, brick or adobe depending on the availability of the material, and one or two floors where the wooden structure overhang the street; and also having a backyard. The most modest houses were ground floor houses (Arízaga Bolomburu, 1990; González García, 1988; Ladero Quesada, 1998; Álvarez Álvarez, 1992) (Figure 3).

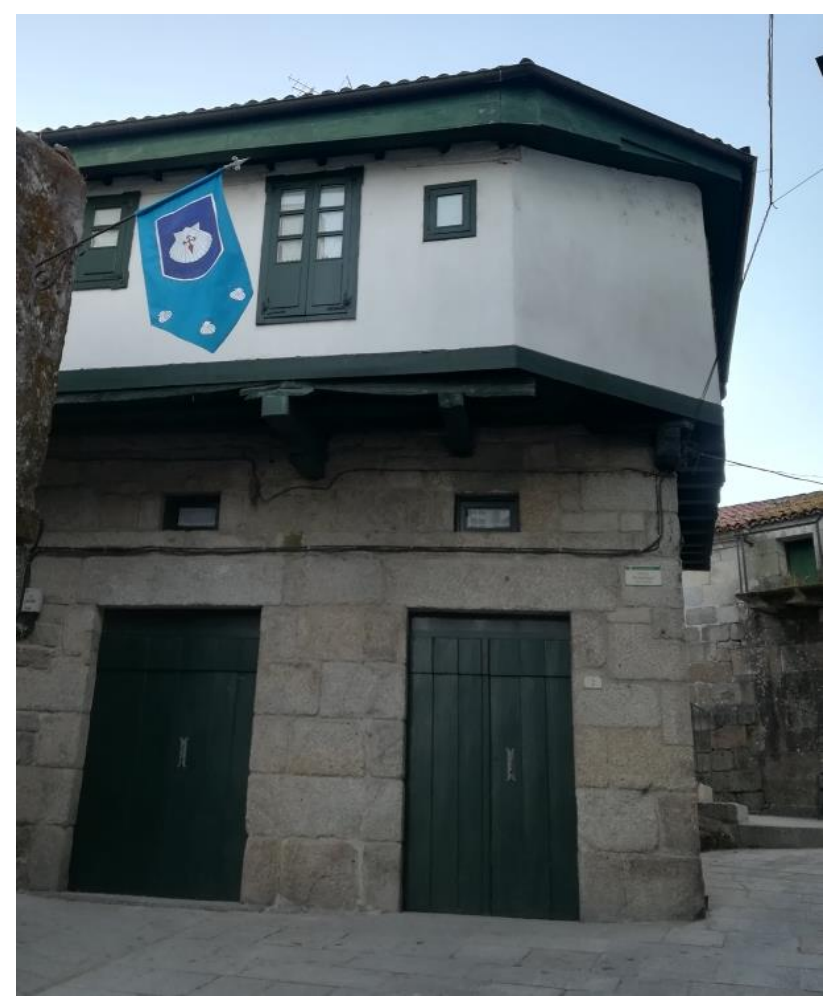

Figure 3. Medieval typology house in the city of Ribadavia, with a ground floor of stone and a half-timbered with earth first floor. Source: A.F.P. 
The appearance of the storeyed house will also have its repercussions on the evolution of rural housing (García Camino, 1998) (Figure 4).

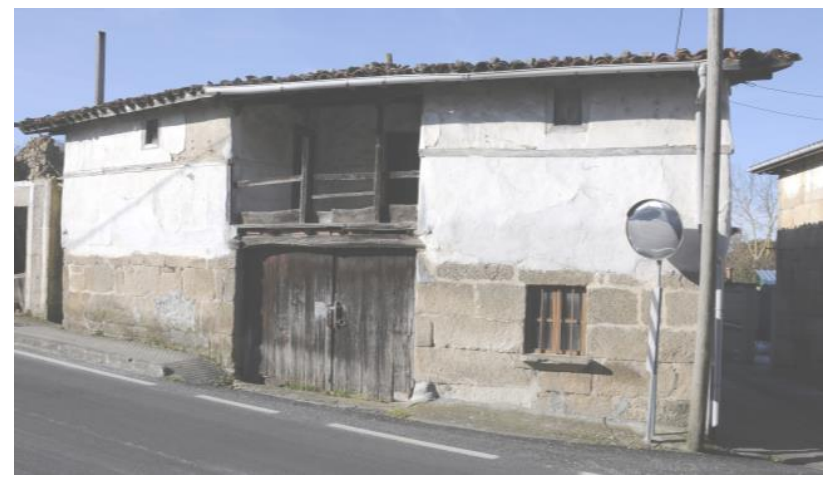

Figure 4. Rural house near the settlement of Maceda with halftimbered with earth floor. Source: A.F.P.

In the context of Galician, there are several authors who describe the type of framework as present since the foundation of different medieval cities in Galicia, such as in Pontevedra (Armas Castro, 1992), Mondoñedo, Viveiro and Ribadeo (López Alsina, 1976); Santiago de Compostela and Lugo (López Carreira, 1999); or Ourense (Lorenzo Fernández, 1962); or that reference their existence in the current historical urban fabric, as in Celanova and Rivadabia (Otero Pedrayo, 1927) or Verín and Monforte de Lemos (Fernández Palicio, 2012, 2016) (Figure 5).

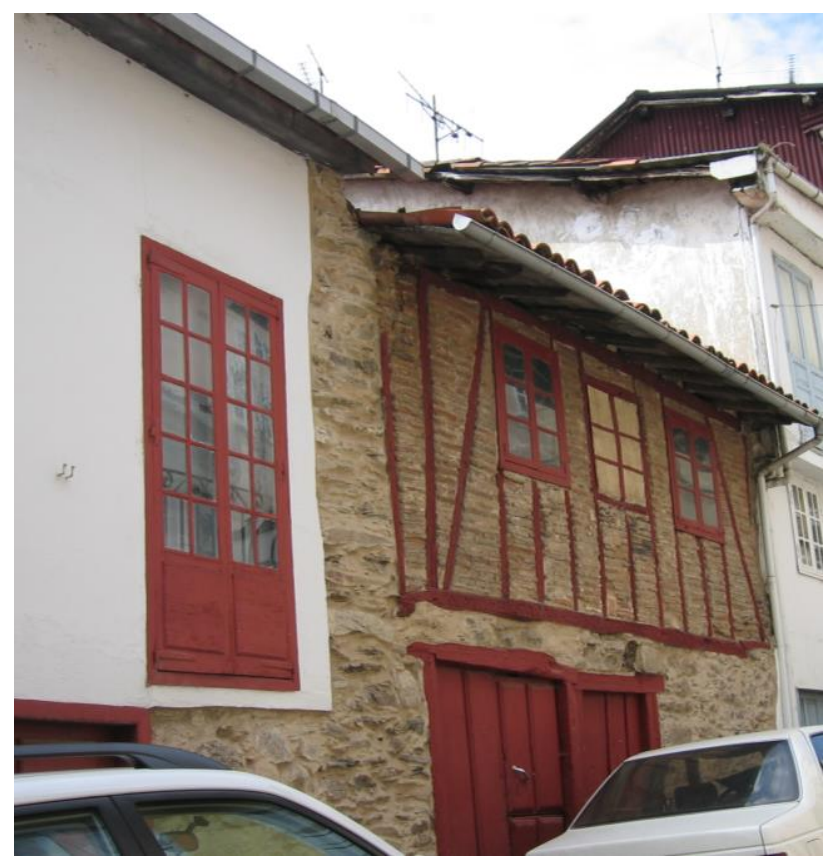

Figure 5. Houses of medieval origin with half-timbered walls with brick filling in Monforte de Lemos. The house on the left modified the facade openings at some later time. Source: A.F.P.

\subsection{Medieval urban housing in Galicia. Types according to} their construction materials.

Ground floor houses were the poorest city houses in Galicia, built in stone with a wooden roof. (Armas Castro, 1992).
However, most of the houses had a ground floor and first floor, which was sometimes completed with a sloping ceiling (Figure 6). On many occasions they formed arcades or the floor formed a cantilever over the street.

Among the surviving houses that we have found we can define three types depending on the materials used combined with the structural wooden framework that formed the main frame of the house.

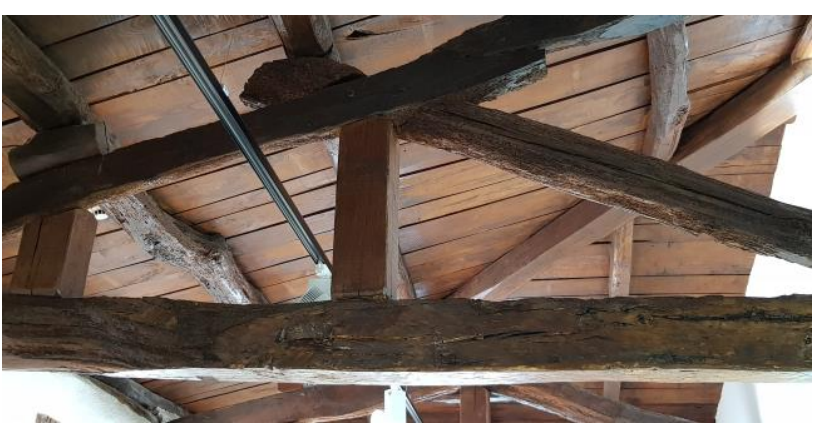

Figure 6. Detail of the wooden framework of the Álvaro Cunqueiro House Museum. Mondoñedo. Source: https://novacarta.eu.

2.4.1 Half-timbered house with plank covering: It corresponds to the oldest typology of dwelling of medieval origin in which the framework is only closed on the outside and inside by a plank. Its use should have declined due to the proliferation of fires in the cities that forced the regulation of construction by means of ordinances that forced the filling with clay or brick to mitigate its combustibility. Currently we have only found examples of these homes in the city of Muros (Figure 7).

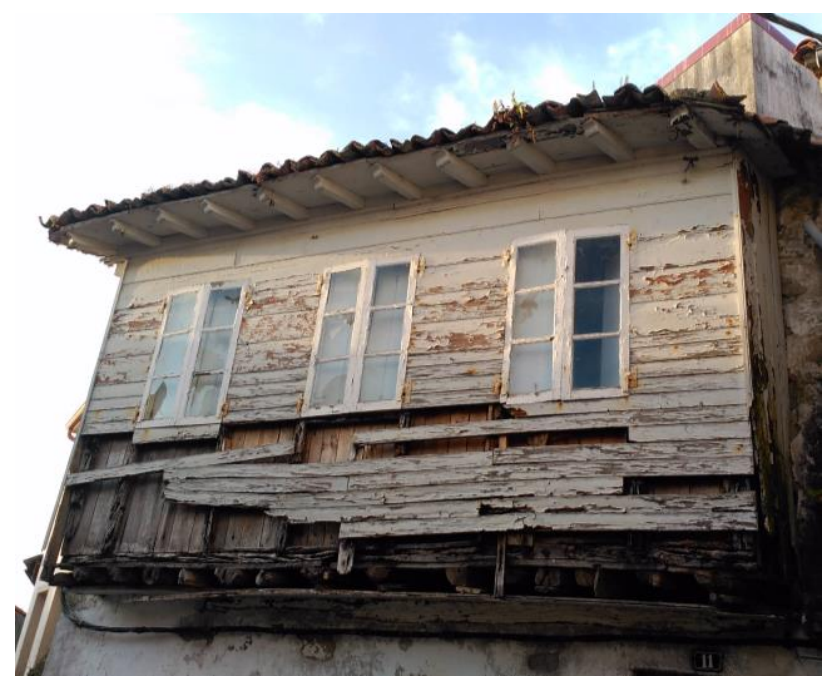

Figure 7. Half-timbered house with plank covering in Muros. Source: Muros City Council Rehabilitation Office

2.4.2 Half-timbered house with earth filling: We still find it in numerous Galician cities both in houses that are preserved (Santiago de Compostela, Ribadavia, Ourense, Mondoñedo, Verín) and in houses referenced in the bibliography (Celanova) (Figure 8). Its use according to some authors will become general from the XIV century (Arízaga Bolomburu, 1990) (Figure 9). 


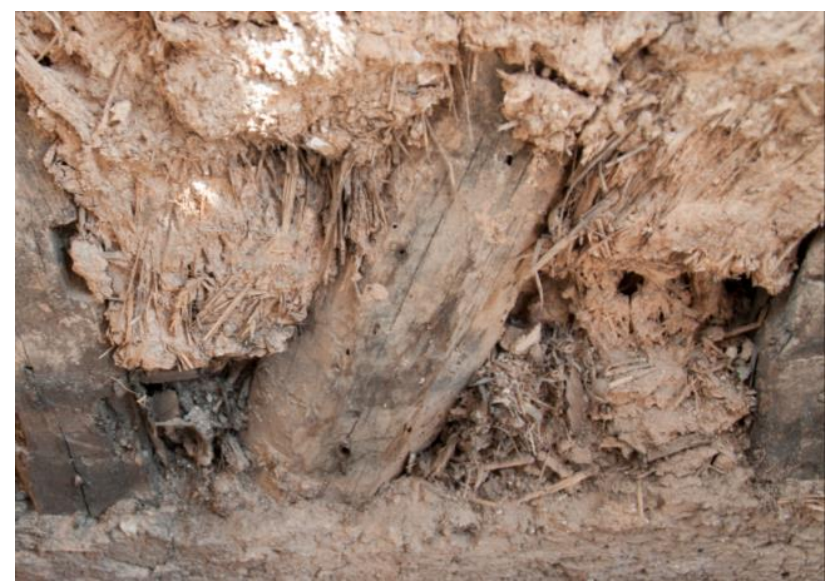

Figure 8. Detail of the half-timbered wall with earth in a house in Ourense. Source: A.F.P.

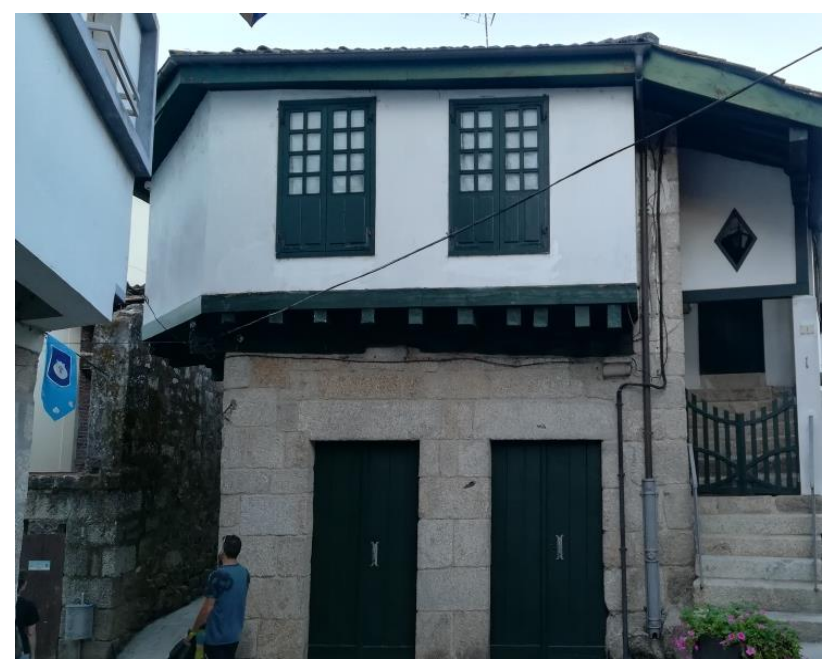

Figure 9. Half-timbered house filled with earth filling in the city of Ribadavia. Source: A.F.P.

2.4.3 Half-timbered house with brick filling: Brick as a building material for dwelings began to be manufactured throughout Europe from the XIII century, including the Iberian peninsula, with a widespread use during the 14th century. (García Camino, 1998). In Galicia, its use should present a similar chronology, with examples in Mondoñedo, Santiago de Compostela and Monforte de Lemos (Figure 10).

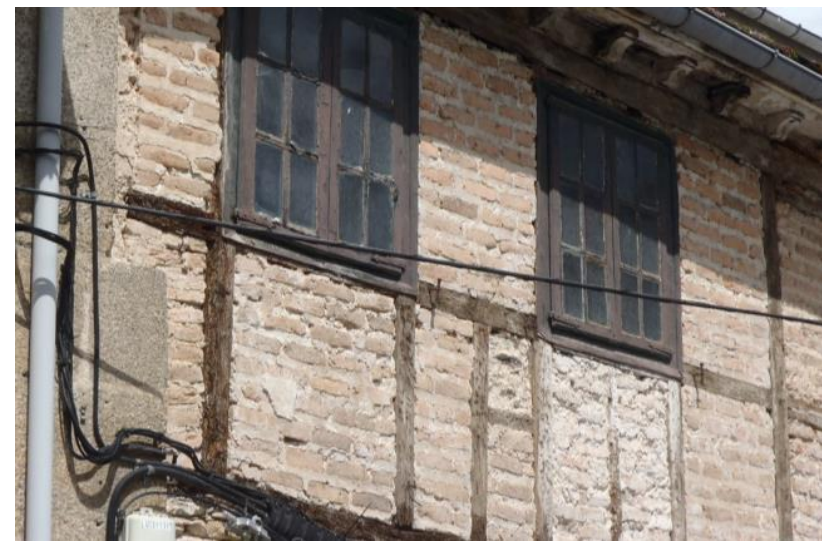

Figure 10. Detail of the half-timbered wall with brick in a house in Mondoñedo. Source: A.F.P.

\section{SANTIAGO DE COMPOSTELA, THE CITY OF WOOD}

Santiago de Compostela at the beginning of the XVII century still had a medieval aspect, with dark and winding streets that responded to the logic of the natural settlement, full of overhangs and with few public spaces.

It was a crowded city behind its walls, entirely occupied by houses that were generally made of wood, narrow and very dark (Vigo Trasancos, 1995).

The Renaissance ideology managed to make some openings in the fabric: in the plaza and Colexio Fonseca, in the Colexio Santiago Alfeo and especially in the Plaza do Obradoiro next to the Royal Hospital and the new cloister of the cathedral. The rest of the fabric will hardly change (Costa Buján, 2015). In 1581 Bourdelot, a traveler, describes Compostela as "A fairly large city, built of wood, but poorly done" (Tellechea Idígoras, 1965) and in 1586 Confalonieri says that "The houses in Compostela are small, narrow and low. They are poorly built. Most of them have plank facades" (Guerra Campos, 1964).

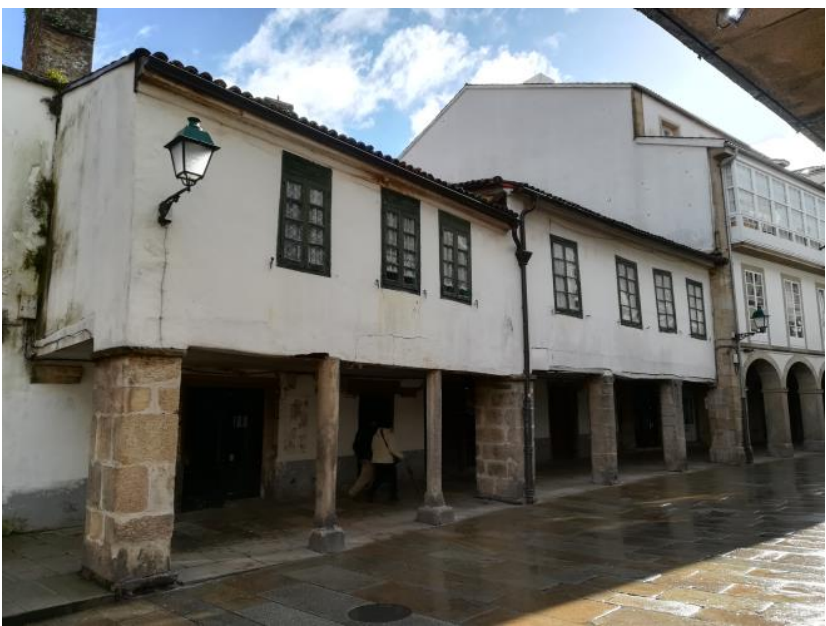

Figure 11. Houses with arcades in the Rúa Nova in Santiago de Compostela. One of the few preserved examples of housing typology with arcades and half-timbered structure with small holes. Source: A.F.P.

In 1607, Cardinal Jerónimo del Hoyo describes the city in this way:

Some of the buildings and streets of this city are fine and carved in stone. Some have tall and strong towers, whereas the old houses are narrow, poorly built and dark. Houses are too close together and lack patios and light. Roofs and ceilings are made of planks and sometimes partitions too. Streets are full of smoke which contributes to an overall dark atmosphere.

It has many streets, but bad; two of them cross the city (...) none of them is straight or equal, because in parts they are very narrow and in wide parts and in many very one-eyed. Two other streets, which are called Rúa Nueva and Rúa del Villar, are good streets, although not very long, but the many arcades they have, but many are very bad and where they have not seem very good. Without these, there are many streets and alleys, but all of them are universally badly cobbled (Costa Buján, 2015) (Figure 11). 


\subsection{The 'petrification' of the city}

From the middle of the XVII century until the last third of the XVIII century, the good economic situation of the religious sector, which will be joined by the bourgeoisie and the nobility, will promote a development boom that will lead to an important transformation of the city with the construction of new palaces on the main streets.

Thus will begin the most significant process in the urban landscape of Compostela, the progressive replacement of wood construction techniques with others that preferably used stone, in a slow process of petrification of the city (Vigo Trasancos, 1995) which will be further promoted after the publication of the Police Ordinances of the city of Santiago in 1780. The document established guidelines for the construction and renovation of buildings and norms for the urbanization of public spaces, thus achieving the modification of the old medieval fabric giving it its current appearance.

Likewise, the window openings were expanded with the appearance of the balconies and the air doors through which they were accessed (Figures 12).

In this way, the urban image of the city was completely changed, replacing half timbers with earth or brick buildings, with stone facades with regular holes and straight planes, as well as stone slab pavements in the streets (Figure 13).

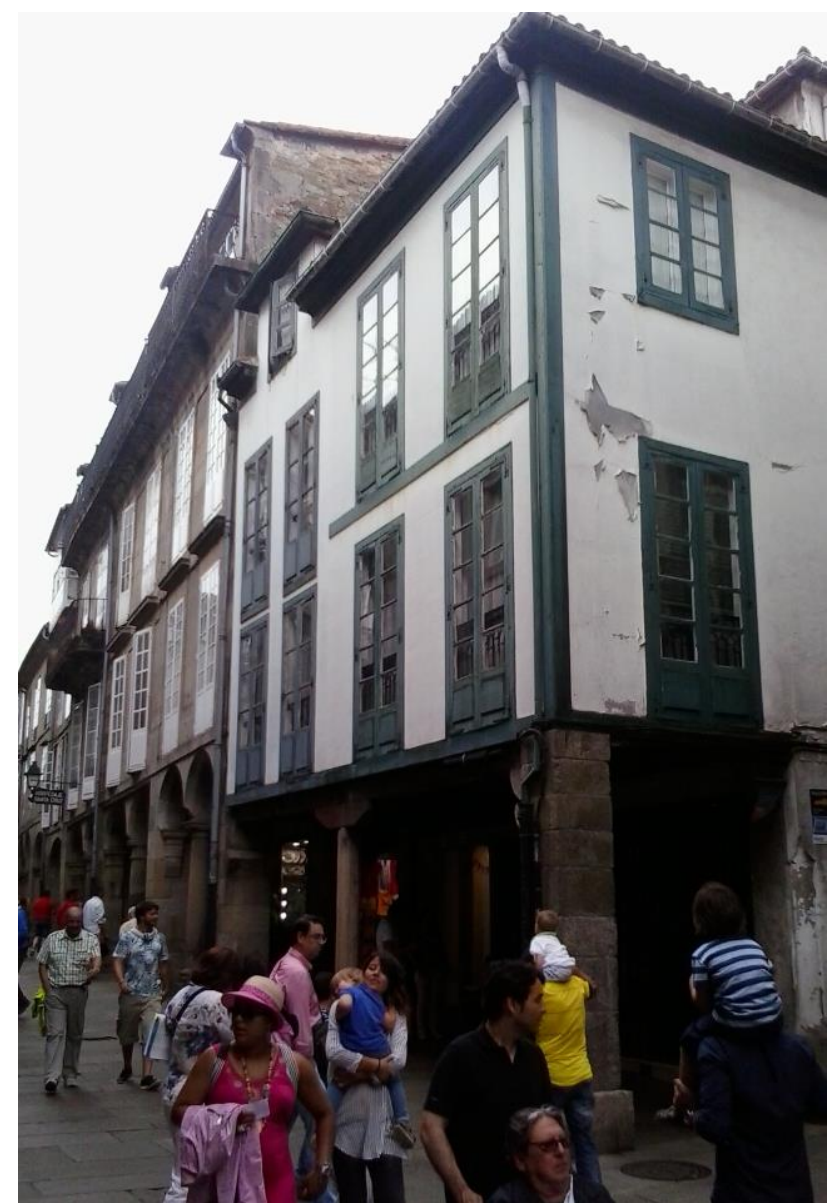

Figure 12. Houses with arcades in the Rúa Nova in Santiago de Compostela. An example of how the half timber typology evolved, conserving the arcade but increasing the façade openings and adding a floor. Source: A.F.P.

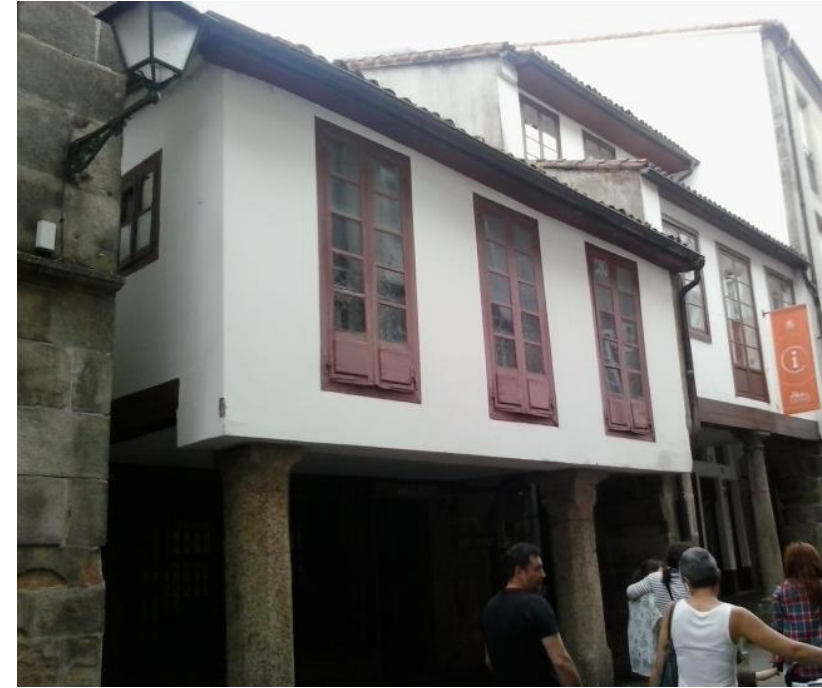

Figure 13. Housing with arcades in the Rúa Nova in Santiago de Compostela. Another example of how the timber frame typology evolved, conserving the arcade but increasing the façade openings. Source: A.F.P.

\section{MONDOÑEDO. THE EVOLUTION OF THE CITY}

Mondoñedo was founded in the XII century, developing as an important commercial center during that century and as a religious center as an episcopal see since the XIII, when its Gothic cathedral was built.

In the fourteenth century it erected its defensive walls that already in the fifteenth century overflowed a series of suburbs, at which point it suffered a great fire that destroyed much of the city, although it would continue to grow until the loss of the provincial capital in 1833 (López Alsina, 1976) (Figure 14).

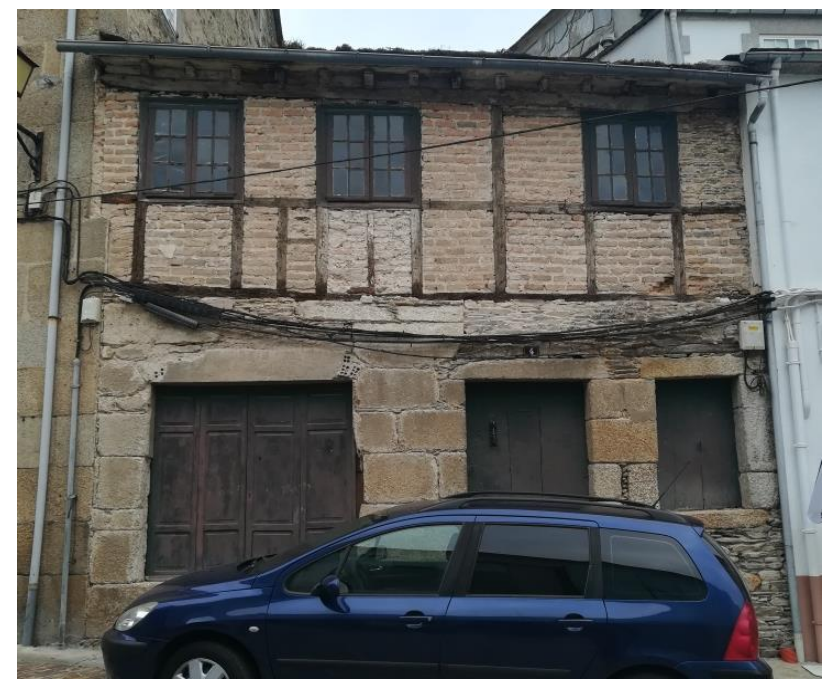

Figure 14. One of the examples of a medieval half-timbered house with brick filling and a stone ground floor that preserves the openings in the façade without modifying it. Source: A.F.P.

\subsection{The evolution of the half timbers in Mondoñedo}

The analysis of the house that today hosts the House Museum of the writer Álvaro Cunqueiro in the Plaza de la Catedral, allows establishing an evolution in the framework of the houses themselves (Figure 15). 
Thus, the house conserved, in its interior structural walls, details of the half-timber filled with earth according to similar ones found in the city of Ourense (Fernández Palicio, 2018), while the main facade, which is made with a half-timber brick-filled, is more regular, with encounters forming right angles to adapt to the fired brick filling.

These two types (Figure 16) presuppose the existence of two stages in the half timbers of the city. A transformation that could be due to the consequences of the important fire that destroyed much of the city in 1425 , or that is due to changes in construction techniques resulting from the introduction of fired brick or the need to reconfigure the facades for the sake of a new social interest as described for other moments in Santiago de Compostela or Ourense (Fernández Palicio, 2018).

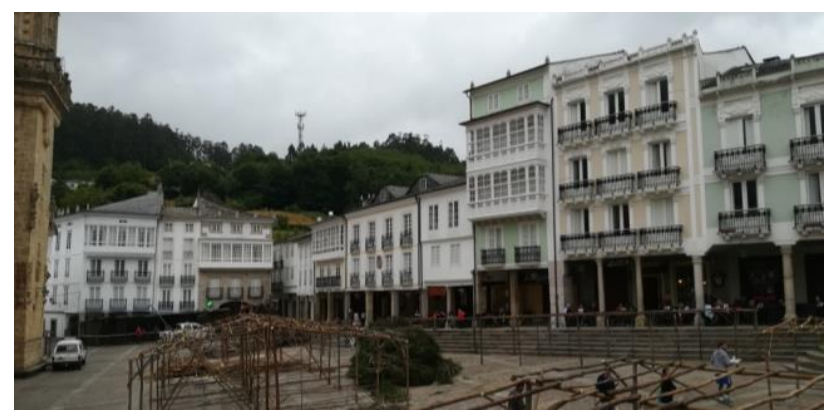

Figure 15. Houses with arcades in the main square, with halftimbered houses and their subsequent evolutions, among which is the Álvaro Cunqueiro House Museum. Source: A.F.P.
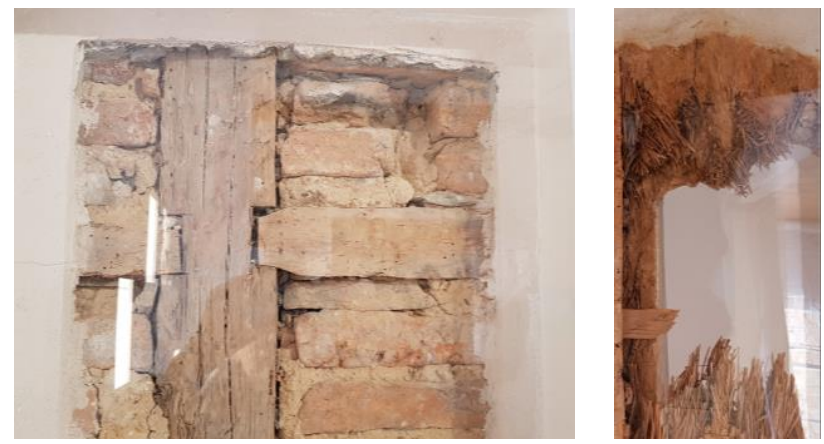

Figure 16. Details showing the half-timbered structure with the brick filling of the facade and an interior half-timbered with earth in the Álvaro Cunqueiro House Museum. The facade was made at a later time. Source: https://novacarta.eu.

\subsection{The transformation of the city}

Mondoñedo was a city of medieval design in the layout of its streets and houses until the eighteenth century (Figure 17) (Figure 18), a period when great development begins, which will last throughout the century.

The economic boom of the local context will allow the different prelates of the see to transform the urban fabric of the city, raising new residential and religious buildings and new services and civic buildings. "Everything was built or rebuilt during the eighteenth century" (Vigo Trasancos, 1999).
It is in this period when a large part of the half-timbered houses will disappear, being replaced by baroque-style houses, with stone facades and dividing walls that sought to reflect the growing ecclesiastical power of the city.

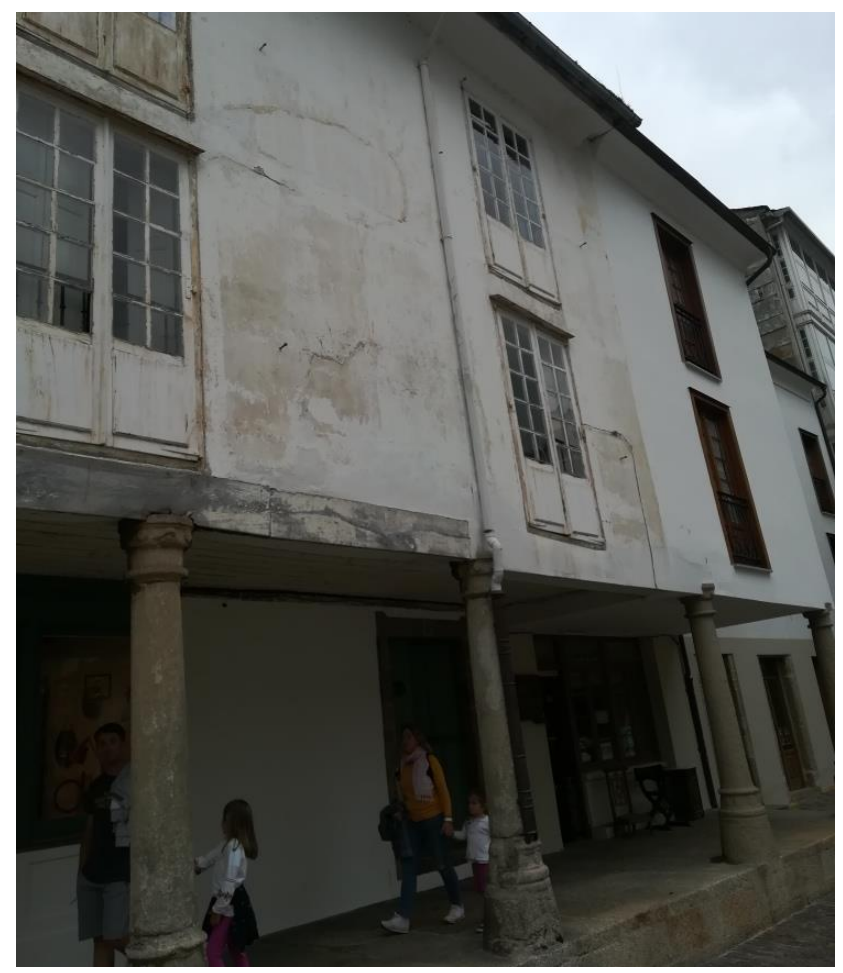

Figure 17. Half-timbered houses with large openings in the façade in Pascual Veiga Street. Source: A.F.P.

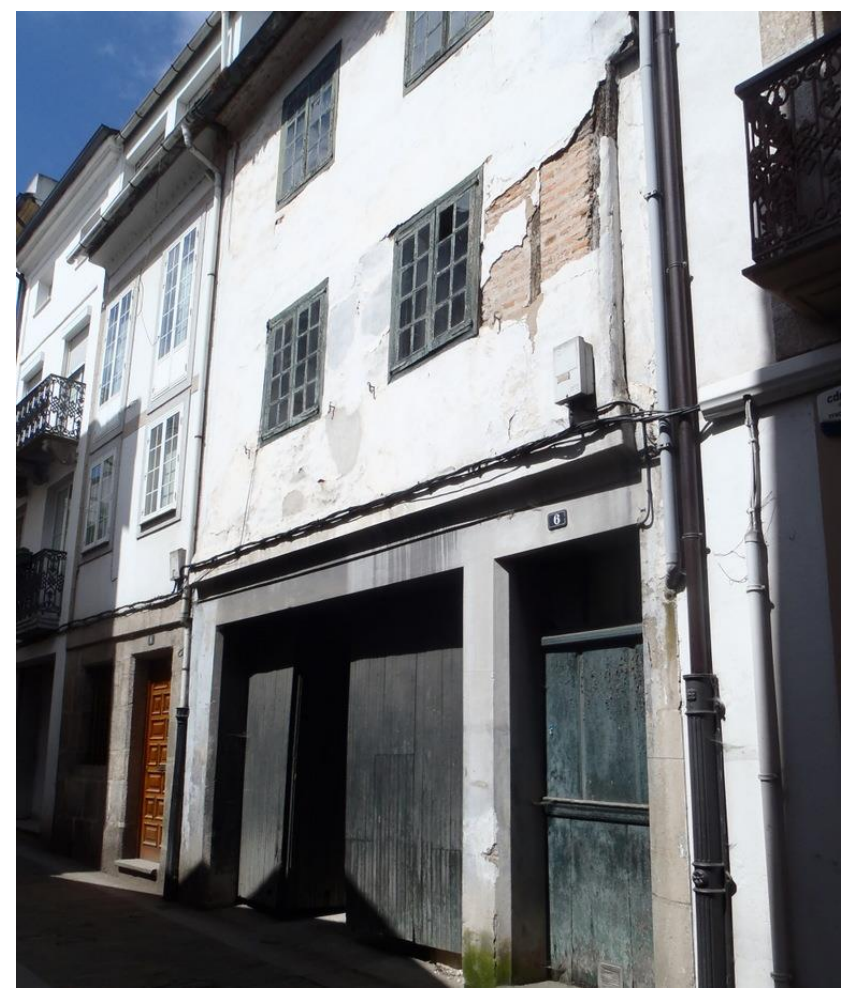

Figure 18. Half-timbered with brick house with a modified ground floor in Guevara street. Source: A.F.P. 


\section{CONCLUSIONS ABOUT URBAN HALF-TIMBER HOUSING}

The half-timbered house was the main construction of the medieval city in the main Galician cities, in which it defined its urban image for more than 500 years.

The cities during this time slowly evolved, which led to the adaptation of the half-timber typology itself, which changed from a primitive type of plank-covered dwelling to a dwelling filled with earth or brick, depending on the availability of materials (Figure 19).

The changes in the perception of the image of cities, the consolidation of certain social classes, the proliferation of fires, the availability of materials, technical improvement and the occasion of periods of economic boom, explain its decline as the main urban typology and its replacement by another erected in stone.

Its study allows widening knowledge of the evolution of vernacular architecture and broadening the field of vision of the discipline.

\section{ACKNOWLEDGMENTS}

We appreciate the help received in preparing this communication to the workers and cicil servers of the Santiago de Compostela Rehabilitation Office, the Santiago de Compostela Consorcio, the Mondoñedo Rehabilitation Office and the Batitales Association, the Muros Rehabilitation Office, the Ribadavia Rehabilitation Office, the Noia Rehabilitation Office and the Pontevedra Rehabilitation Office as well as the technicians and owners who kindly helped us.

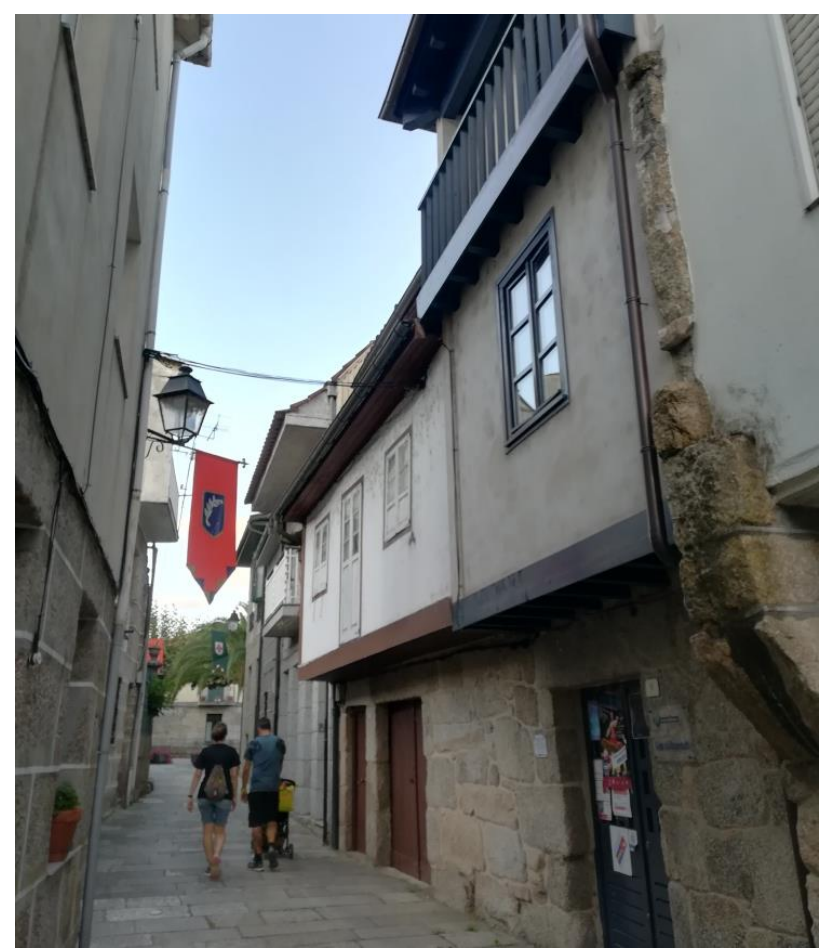

Figure 19. Cantilevered half-timbered houses in Ribadavia. Source: A.F.P

\section{REFERENCES}

AAP (Associaçâo dos arquitectos portugueses) 1988. Arquitectura popular en Portugal; 3 vol. Zonas 1 e 2. Lisboa.

Álvarez Álvarez, C., 1992. La ciudad de León en la baja Edad Media: el espacio urbano. Hullera Vasco-Leonesa. Madrid.

Arízaga Bolomburu, B., 1990. La arquitectura medieval en la Edad Media (Guipúzcoa). Revista de la Facultad de Geografía e Historia, 4. San Sebastián.

Arízaga Bolomburu, B., 1993. El paisaje urbano en la Europa medieval. III Semana de estudios medievales. Nájera.

Armas Castro, X.A., 1992. Pontevedra en los siglos XII a XV: configuración y desarrollo de una villa marinera en la Galicia medieval. Fundacion PBM. A Coruña.

Bas, B., 2002. As construccións populares, un tema de etnografía de Galicia. Do Castro. A Coruña.

Bohuier, A., 2006. Galicia: Ensaio xeográfico de análise e interpretación dun vello complexo agrario. CAGM. Compostela.

Caamaño, M., 2006. As construccións da arquitectura popular. Patrimonio etnográfico de Galicia. Hércules. Coruña.

Costa Buján, P., 2015. La ciudad heredada. Teófilo

De Llano, P., 1981, 1983. Arquitectura popular en Galicia. COAG. Compostela.

De Llano, P., 1996. Arquitectura popular en Galicia. Razón e construcción. COAG. Compostela

Feduchi, L., 1977. Itinerarios de Arquitectura Popular Española. Blume. Barcelona.

Fernández Palicio, A.; 2012. Earth construction in Galicia: Rammed earth in Lemos. Rammed earth conservation. Mileto, C., Vegas,F., Cristini,V. (Eds.), Taylor and Francis Group.

Fernández Palicio, A. 2016. Construcción con tierra en la cuenca del Támega (Galicia). Congress TerraLyon2016. Grenoble.

Fernández Palicio, A.; 2018. Earth construction in Ourense. Vernacular and Earthen Architecture: Conservation and Sustainability. Mileto, C., Vegas, F., García-Soriano, L. (Eds.) Taylor and Francis Group.

Flores López, C., 1973. Arquitectura popular española. Aguilar. Madrid.

García Camino, I., 1998. La vivienda medieval: perspectivas de investigación desde la arqueología. La vida cotidiana en la Edad Media. Nájera.

García Oro, J., 1987. Galicia en los siglos XIV y XV. Fundacion PBM. A Coruña.

Guerra Campos, J., 1964. Viaje de Lisboa a Santiago en 1594. Cuadernos Gallegos, XIX.

González García, M. 1988. Salamanca: la repoblación y la ciudad en la baja Edad Media. Salamanca. 
Laredo Quesada, M. F., 1998. La vivienda: espacio público y espacio privado en el paisaje urbano medieval. La vida cotidiana en la Edad Media. Nájera.

López Alsina, F., 1976. Introducción al fenómeno urbano medieval gallego, a través de tres ejemplos: Mondoñedo, Vivero y Ribadeo. USC. Compostela.

López Alsina, F., 2014. La ciudad de Santiago de Compostela en la Alta Edad Media XII. USC. Consorcio de Santiago.

López Carreira, 1999. A cidade medieval galega. A Nosa Terra. Vigo.

López Cuevillas, F., 1973. Prehistoria. Historia de Galicia. Volumen III. Galaxia. Vigo.

Lorenzo Fernández, X. 1962. Etnografía. Cultura Material. Historia de Galiza. Otero Pedrayo. Nós, Buenos Aires.

Mayán Fernández, F., 1994. Historia de Mondoñedo desde sus orígenes hasta 1833, en que dejó de ser capital de provincia. Deputación de Lugo.

Otero Pedrayo, R., 1927. Parroquia de Trasalba. Revista Nós. Ourense.

Rodríguez del Cueto, F., 2012. Arquitecturas de barro y madera prerromanas en el occidente de Asturias: el Castro de Pendia. Arqueología de la Arquitectura. Madrid/Vitoria.

Rosende Valdés, A., 2005. Una historia urbana. Compostela 1595-1780. Nigra Trea. Gijón.

Sanchez Carrera M.C., 1997. El Bajo Miño en el siglo XV: el espacio y los hombres. Fundacion PBM. A Coruña.

Solano Fernández-Sordo, Á., 2010. Historia urbana en la galicia medieval. Balance y perspectivas. Cuadernos de Estudios Gallegos, LVII, N. ${ }^{\circ} 123,55-90$.

Tellechea Idígoras, J.L., 1965. Un peregrino veneciano en Compostela en 1581, (del diario inédito de B. Bourdelot). Compostelluanum.

Vigo Trasancos, A. M., 1995. Santiago 1600-1770. La metamorfosis barroca de un santuario de peregrinación. Santiago de Compostela: La ciudad histórica como presente. Martí Arís, C. Consorcio de Santiago.

Vigo Trasancos, A. M., 1999. La ciudad de Mondoñedo en el siglo XVIII. La renovación urbana de una antigua sede episcopal. Estudios mindonienses: Anuario de estudios histórico-teológicos de la diócesis de Mondoñedo-Ferrol, 15. 